Chapter 4

\title{
Continuity over change: Belarus, financial repression and reintegration with Russia
}

\author{
Julia Korosteleva
}

\section{Introduction}

From the late 1980s transition economies began to transform into market economies and reintegrate with global markets. This chapter examines the case of Belarus, focusing primarily on developments in its financial sector and its strategy of integration into the global economy. The nature of transition in Belarus is the same as elsewhere in the post-communist world, but it is different in its policy-making and chosen path of integration into the global economy. Indeed, while most of the Central and Eastern European (CEE) countries embarked upon the transformation of their economies from early on in the post-communist era and were in general strongly committed to moving towards a market economy along an 'orthodox transition path', Belarus has often been retroactive, ducking the challenges of transition and introducing the elements attributed to the repressed economy, particularly in the financial sector. The latter was believed to sustain the government strategy of economic growth. Indeed, Belarus has demonstrated macroeconomic growth from 1997 onwards comparable to that in the Central European transition countries regarded as successful in transition. Belarus differs from other transition economies not only in its divergent policy-making during the years of transition, but also in its chosen strategy for integration into the global economy. After the USSR collapsed, it made its 'radical' choice in favour of unification with Russia, rather than pursuing a strategy of EU accession as a majority of CEE countries did. However, since 1993 when the issue of Belarus-Russian integration first emerged on the agenda of the two countries, actual, substantive moves to reunification have amounted to little more that the signing of agreements. There has been little real action to promote union especially on the Belarusian side. However, with Putin's accession to power in Russia, new constraints have challenged the Belarusian mode of economic and political development, forcing some change.

In order to try and explain how Belarus is a divergent case, we need to have some idea of what it is that it is diverging from. To this end, the first section of this chapter reviews the initial shocks that all transition economies face at the beginning of transformation and discusses patterns of transition in finance. Revealing, that financial repression became the pillar of economic policy-making in some of the FSU countries, such as Belarus, relying on the strategy in maintaining the output, we discuss the meaning and the reasons of financial repression in the second section. It presents us with the findings about existing significant correlation between financial repression and political stance. In turn acknowledging that the choice of introducing financial repression in Belarus in first place was determined politically to assure the political viability of those in power brings us to the discussion of politicalization of economic-policy making in Belarus in the third section. The forth section briefly stresses the grounds of the Belarusian economic model to unveil the role of the financial system in it in the following section. Reviewing the developments in the 
financial sector over 90s lets us answer the question how necessary was to introduce financial repression in 1996 and what was the real impact of it on the economic development in Belarus. The final section scrutinizes the divergent post-communist pathway of Belarus by investigating its strategy of integration into the global economy, and outlining further perspectives on the development of the country.

\section{Distinguishing the pathways of transition economies}

The initial shock for all transition economies was the collapse of the administrative planned system itself. It predetermined the transformational recession in emerging countries marked by initial fall in output. The collapse of the CMEA resulting in the breakdown of trade agreements, the elimination of subsidies and the increase in prices of imported energy and gas, the decrease in aggregate demand due to priority in policy-making given to stabilisation and so forth aggravated the downward trend of output in post-communist countries. At the same time, price liberalization caused a strong upward inflationary pressure. It is reasonable to assume that the best policy mix in these circumstances would address both the decline of output and the sharp surge in inflation. However, the orthodox approach to this issue favoured the policy of curbing inflation by all means and was to reduce central bank credit since excessive money supply was regarded as the primary cause of inflation. Liberalisation, stabilisation, privatisation, cut in government expenditures and so forth appeared to be a set of policies regarded as a common remedy for all transition economies to achieve the success in transformation. This pattern of transition was characterised by a sharp initial fall in output at the expense of social costs and then recovery and growth followed.

Countries that were strongly committed to driving towards the free market - most of the CEE countries and the Baltic countries - followed the orthodox approach and introduced deflationary policies with high positive interest rates and the tightening of money emission as the major anchors of stabilization policies. ${ }^{1}$ These policies of credit restriction induced domestic enterprises to turn to non-bank money via the use of barter and increase of inter-enterprise arrears. In turn, this policy of credit crunch triggered further sharp drops in output in emerging economies. It also had a negative effect on enterprises that performed well and which deserved to get credit by all standard criteria. Due to an adverse selection effect, they had to pay higher rates of interest on credit. Banks raised their provisions because of bad loans and sought higher profits through higher spreads between their lending rates and the cost of their borrowing from the Central Bank (Lavigne, 1999, p.187). In turn, when capital account liberalisation followed later in these economies, it made enterprises turn to borrowing from foreign markets. Transition economies appeared to be different in their experience of capital liberalisation, as well as in the pace and the sequence of the implemented reforms. As the pace and the extent of removing capital controls vary in each of them, the effects are different either. However, most of these countries underwent banking or currency crises after initiating capital liberalisation. What becomes clear is that liberalisation should be gradual and undertaken after institutional and structural reforms implemented.

Other countries, notably the majority of states of the former Soviet Union (FSU), were slower in responding to the challenges of transition. However, there is need to note that their patterns of transition also vary from country to country and in fact it would be more reasonable to distinguish smaller groups. Such countries as Russia and Ukraine made more progress towards reforms. Belarus, Uzbekistan, 
Turkmenistan have been lagging behind, but performed better in terms of output decline. They chose a policy of maintaining output and employment accompanied by repressed inflation. The liberalization of prices and of foreign trade occurred at a slow pace and subsidies to enterprises still prevailed. Indiscriminate financing of favoured industrial and agricultural enterprises by the banking system continued unabated. This policy of credit emission created inflationary tendencies. The dominant policy of negative interest rates aimed at supporting state-owned enterprises in these countries had a devastating effect on domestic savings. Under these conditions, legal tender began rapidly to lose its credibility. No amount of legislation on legal tender, or the administrative measures introduced in some countries, could make people accept the official currency. Its rate of depreciation in conditions of high inflation reached the point where money lost its attractiveness both as a store of value and as a means of exchange. Dollarization became a common feature of these countries. However, we should note that the problem of substitution of national currency was not only a concern of FSU countries. It was typical, to a greater or lesser extent, across the whole region, particularly at during the early stages of transition. The introduction of a foreign currency component into the money supply makes the policy of monetary targeting more complicated.

The viability of the above policy-making became possible due to the excessive government intervention in the economy resulted in introduction of the mechanism of the repressed economy. Price controls, multiple exchange rate, exchange rate restrictions, and subsidies to state enterprises and so forth can be regarded as the features attributed to the repressed economy. Moreover, repression of the financial system was placed in the centre of this mechanism. Recognising the intermediate role of the financial system between savers and investors, it became viable to impose the restrictions on the financial sector to provide the mechanism of soft-budget constraints working. So, financial repression became the pillar of economic policymaking in some of the FSU countries relying on this strategy in maintaining the output.

\section{The theory of Financial Repression}

Financial repression (FR) can be defined as a set of policies and controls, primarily in a form of interest rates ceilings, high reserve requirements and directed credit programmes, imposed by governments on the financial sector that restrain financial intermediaries' activities. FR and its instruments are widely regarded as a form of taxation.

This phenomenon has been studied in financial development economics. It goes back to McKinnon's (1973) and Shaw's (1973) financial development framework supporting the idea that money and capital compliments each other rather than substitute. It implies the following. As more attractive to hold real money balances, the greater incentive to invest. Therefore, raising interest rates to equilibrium level will increase the rate of economic growth. Neo-classical theory (Tobin, 1965) in turn argues about perfect substitutability of money and productive capital. Therefore, low interest rates (return on money) can increase economic growth through interest-rate ceilings and through the optimal level of inflation. Stiglitz and Weiss (1981) argue that in the presence of imperfect information the equilibrium interest rate may not clear the loans. Their implication is that as interest rates rise, the average risk of projects rises too, possibly reducing the bank's profits. Currently, there is a bulk of literature written on FR and its effects on economic development including Fry, M. 
(1995), De Melo and Giovannini (1993), Demetriades and Luintel (2001). In their majority researchers concluded that FR has a negative impact on maximizing welfare. However, financial repression literature also encounters a great deal of criticism (see Demetriades and Luintel or Stiglitz), recently raised due to the experience of some unsuccessful liberalization episodes in Latin America, Asia and Russia.

The instruments of financial repression, as mentioned above, are high reserve requirements, interest rate ceilings and directed credits. Interest rates ceilings in turn might imply credit rationing by the government due to the excess demand over supply in the loan market. The policies of FR are accompanied by the introduction of capital control restrictions to prevent access by potential borrowers to foreign markets, as well as preventing domestic money holders from switching from savings in banks to purchases of foreign assets.

Different reasons for the use of FR can be named, and which are mostly reduced to fluctuations in government revenue behind which the public finance approach lies. The idea is that the revenue losses from direct taxes can be offset by introducing implicit forms of taxation through FR or inflation tax. In the literature on financial development, along with the concept of FR itself, important attention is drawn to the concepts of seigniorage (S) and inflation tax (IT). All three are regarded as forms of discriminatory taxation of the financial system. IT is a tax on nominal assets. Since most of government debt takes the form of non-indexed nominal assets, the value of that debt is eroded when prices rise. In turn debt-holders suffer a capital loss. Not only householders (currency holders) lose in this case, banks holding fraction of their assets in central bank as required reserves suffer either. The higher reserve requirements, the bigger banks' losses from IT due to increase in the inflation tax base. However, while the inflation tax base is high-powered money, financial repression affects the portfolio of non-monetary assets held by domestic residents, and therefore the distortions in the real interest rates (under condition of nominal interestceilings) due to inflation should be included in the definition of financial repression rather then of inflation tax (see De Melo and Giovannini (1993). De Melo and Giovannini argue it is to be expected that the inflation tax be used together with financial repression. In turn, Fry (1995) argues that in classic cases of financial repression, the proliferation of financial instruments from which governments can extract seignorage is encouraged. For example, this can be done through imposing taxes on private securities markets, because seignorage cannot be easily extracted from these markets. Thus, the absence of private securities markets as such or the lack of their development in some transition economies with financially repressed systems is not surprising. FR together with inflation tax have an overall effect of transferring funds from the financial system to public borrowers.

Returning to the reasons for introducing FR we should specify the following. In transition economies, at least at the early stages of transformation or in some countries even at present, the distinction between public and private is blurred, which implies that along with budget deficit it is common to have quasi-budget deficit. This, for example, explains the phenomenon of low budget deficit in some transition economies when one would assume it to be much higher. In the countries with a high share of the state-ownership, with slow pace of reforms and a high degree of state interference into economic activity (e.g. Belarus) the quasi-budget activities in the form of supplying 'planned funds' or in other words directed credits to state-owned enterprises (SOE) become very common practice.

Whilst studying the issue of FR it is interesting to examine how political stance is correlated with levels of FR. In this regard the findings of Denizer, C, Desai, R.M, 
Gueorguiev, N. (1998) can be implicative. The authors undertake a systematic analysis of the political economy of financial repression in the post-Communist region, explaining how different policy decisions are reached in different political settings. Basically, their findings imply that repressive financial controls may be adopted not to finance deficits more cheaply than would be the case under FL, but to maintain authority and ensure the survival of those in power. Thus, where inter-party competition is low, elites have been able to carry on a system of implicit subsidies by 'softening up' the financial sector to assure the continued flow of 'easy money' to large state-owned enterprises linked to the largest 'commercial' banks. Claims on public resources have been converted into preferential financing from the banks performing the role of state agents (see Denizer, C, Desai, R.M, Gueorguiev, N. (1998).

This presents us with the study case of Belarus as a classical example of a financially repressed economy. Although, it should be acknowledged that in 19941995 some steps were undertaken towards financial liberalization through the introduction of positive interest rates, switching to market auctions as a way of reallocation of credit resources and introducing a policy of monetary tightening. However, the policy was reversed in 1996, and the elements of the repressed economy were introduced. Section 4 deals with the detailed analysis of the developments in the financial sector of Belarus in the 1990s. It explains why the concept of FR can be applicable to Belarus and it is interesting to observe that the choice of introducing FR in first place was determined politically to assure the political viability of those in power that is to be unveiled in the next Section.

\section{Politicalization of economic policy making in Belarus}

Under the Soviet system Belarus was the 'industrial assembly plant' specializing mainly on the production of complete goods. The share of industry in GDP in 1990 accounted for 49 per cent versus 22 per cent the share of agriculture and 29 per cent the share of services. Military-industrial complex accounted for more than a half of its industrial production. The existence of price distortions in the soviet system, which favoured the finished goods towards their overpricing and made the raw materials and agricultural products underpriced, rendered the Belarusian trade a positive balance within the inter-republican trade. So, despite of the lack of natural resources Belarus' economically favourable position within the Soviet Union allowed it to have standard of living well above almost all CIS countries.

After the dissolution of the Soviet Union, the Belarusian authorities represented by the remnants of Communist elite neither were ready for radical reformation of the country, nor expressed their willingness to do that. They were rather keen on preserving the status quo as a substitute for reforming the national economy (see Silitski, 2002, p.226). The strategy of the Belarussian authorities at that time was to preserve the arrangements within the single Rouble zone, trade links with Russia and also to assure the supply of Russian oil and gas at a price that existed on the Russian internal market. All the above helped the Belarusian economy to avoid a sharp decline in production that was typical of the region, and guaranteed a temporary political survival for the Belarusian leadership. The initiation of integration issue with Russia by Kebich in 1993 (prime minister from 1990 to 1994 and a presidential candidate in 1994) was bound by the chosen populist strategy aiming to win the favour of population that felt nostalgia about the Soviet Union and represented the majority of electorate in 1994. Moreover, lobbying this issue together with the achieved trade-offs 
between Russia and Belarus in other areas of cooperation ${ }^{2}$, allowed the Belarusian nomenklatura to avoid reforming the economy due to the economic concessions gained from Russia. This issue is to be expanded more in Section 6.

Despite undertaking the measures described above to prevent a sharp decline in output, Belarus nonetheless went in transition recession due to the reasons named in section 1. Kebich's government responded to it with the policies aiming to minimize the social costs that are to prevent a decline in real wages and employment. Namely, subsidies to enterprises at budgetary expenses and through directed credit programmes were introduced to maintain output. Social guarantees and control of consumer prices acted as pillars to prevent the decline in income. However, the expansionary policies put pressure on inflation, which averaged 2,000 per cent per year in 1993-94, and deteriorated the situation in the real sector of economy with output continuing to decline further. At the eve of the 1994 presidential elections Kebich's government quickly lost its political standing due to the worsening of macroeconomic situation and declining living standards of the population.

Immediately after Alexander Lukashenko's accession to power in 1994, there can be observed some changes in the economic policy-making in Belarus. This period was characterised by the introduction of some steps towards market-oriented reforms. With Bogdankevich, a neo-liberal economist, being a chief of the National Bank of Belarus (NBB) 1994-95 were marked by a tight monetary policy and the policy of positive real interest rates. These efforts resulted in achieving relative stabilisation in the economy, which is expanded on in Section 4. However, all these observed positive changes in the economic policy-making in 1994-95 were not due to the adherence of Lukashenko's government to market-oriented reforms, but rather due to the inevitability of initiating them in view of the continued worsening of macroeconomic situation and the frozen relations between Belarus and Russia. Indeed, at the beginning of Lukashenko's leadership the cooling in Moscow-Belarus relations could be observed. Lukashenko appeared at the political scene as an outsider that made Moscow suspicious of him. The prospects of the monetary union and subsidized energy supplies became questionable, as Russian officials openly declared that the promises of both were made in anticipation of the election of Kebich into presidency, and were conditioned by the eventual political unification, which Lukashenko was not yet ready to pursue (See Silitski, V, 2000, pp. 229-230). That is why during 1994-95, just after his election, Lukashenko seemed to have given up from almost all his electoral promises of maintaining the price control and reintegration with Russia, and switched to a more radical course of economic transformation through tightening a credit-monetary policy and cutting subsidies to some state enterprises and partly liberalizing prices. However, further deterioration of economic situation in Belarus would have undermined his popularity and triggered Lukashenko turned towards Russia for a political, economic, as well as symbolic support. Although 1994-95 was sort of watershed between an uneven and chaotic Kebich's policy and more systemdefined policy of Lukashenko, it still can be regarded as a poor attempt to stabilize the economy, because it was not undergone any in-depth transformation as such.

1996-2000 were marked by reversing the political-cum-economic course and introducing the elements of the repressed economy mentioned earlier in Section 1. The strategy pursuing by Lukashenko (to be discussed in details in Section 4 and 5) managed to bring some visibility of success resulted in economic growth starting from 1997 onwards, but questioned its sustainability in a long run. Next section deals with the issue of economic growth in Belarus at the end of 90s and the factors contributed to this 'Belarussian miracle'. 


\section{Whither the 'Belarussian miracle'?}

The case of Belarus is particularly intriguing because despite undertaking no transformation per se, and achieving no macroeconomic stability, Belarus has nevertheless demonstrated macroeconomic growth from 1997 onwards comparable to that in the Central European transition countries regarded as successful in transition. Inflationary creation and state stimulation of demand through policies of an unprecedented credit expansion, negative interest rates, and administrative price control seem to contribute to economic growth from 1997 onwards.

Admitting a decrease in aggregate demand as one of the factor of output decline, the government stressed the strategy of state stimulation of demand through policies of an unprecedented credit expansion and negative interest rates as central ones in achieving the economic growth. However, it was difficult to implement them unless government had a high control over the economy. The state control could be easily established through preserving and increasing the state ownership. It became possible due to the reversal of privatisation programme. In 1995 privatisation became rather artificial that presupposed turning the state enterprises into joint-stock companies with the state share prevailed or being more than 25 per cent that meant preserving the state control over the managerial decisions. That was strengthened by the 'golden share' right introduced by the government in 1997. The state control had also to be introduced in the financial system. It was literally done through the renationalization of the banking system in 1995-1996. Moreover, it required the National bank to be subordinated to the government. All these issues will be considered in more details in the next section.

Declaring a socially-oriented market economy as a key direction of the economic development of Belarus, Lukashenko had all the instruments to manage his 'puppetshow'. First of all, due to the set of policies described above the Belarusian economy achieved an astounding 10.7 per cent rate of economic growth. The grounds for this growth were the reintroduction of the mechanism bearing a strong resemblance with a planned economy. State ownership, 'planned funds', price subsidies, and repressed inflation - they all recognised as the elements of administrative planning economy. While the mechanism of resource allocation based on channelling the funds from those having a surplus to those having a deficit was typical in the Soviet economy, in the Belarusian economy it was realised not only through the directed credits supplies to preferential sectors of the economy, but also through such indirect instruments as relief from paying some taxes and customs duties by the 'strategic' sectors of the economy at the expense of increasing tax burden on a private sector, licensing of certain economic activities that aimed to crowd out the potential competitors from the market, rationing access to cheap natural resources, multiple interest rates, multiple exchange rates, restrictions in foreign exchange markets and price distortions. It is fair to note that multiple exchange rates, restrictions in foreign exchange markets and price distortions were also exercised in a planned economy to large extent. However, what is remarkable is that under the Soviet economy all the enterprises were relatively equal in terms of their eligibility to subsidies upon the condition of running deficit, while in the present system the preferences are given to strategic state-owned enterprises that in the end are supported at the expense of the private sector, the households and the financial system.

Lukashenko's 'show' succeeded. The measures introduced facilitated an increase in short-term living standards that raised Lukashenko's popularity among the 
Belarusian people. On pursuing the strategy of maintaining full employment, Lukashenko banned layoffs in the industrial sector. Moreover he was increasing real wages through the periodic credit injections into the public enterprises, provided subsidies to poor people, banned price increases and so forth. However, the longer the 'show' lasted the more obvious the cracks in the 'scenario' became. The strategy had rather short-run effects and was not sustainable in a long run.

While discussing the policy mechanism allowed achieving the economic growth in 1997, there have not been yet named the components of GDP that contributed to this 'miracle'. Well, it goes beyond the scope of this Chapter. However, for the reader to understand the full picture of Belarus' recovery, there is need to outline them briefly.

The policy of money-led stimulation of the aggregate demand triggered the surge in households' consumption and investment in 1997. What is interesting is that the share of inventories declined in 1997-1999 demolishing the arguments that tried to explain the economic growth solely by the increase in the stock of unsold goods. The increase in inventories was registered first in 2000 after the years when the growth of Belarus' economy started. The surge in investment activity was mainly due to the strong growth of housing construction in turn financed primarily by directed credits at highly preferential rates (see the next section). Industrial output expansion and housing construction, and trade slightly lagging behind, were the main branches of the economy contributed to the economic growth in late 90s. Among the other factors due to which the economic growth became possible should be named the role of Russia that appeared to be significant in sustaining the economic growth in Belarus (to be expanded in section 6). Finally, GDP growth can be partly explained by some statistic tricks and the practice of multiple exchanged rates. Upon the conditions of persistent current deficit GDP was always overestimated due to the use of the official exchange rate in the national statistics that was 60 per cent lower than the market rate.

Concluding this section there is need to stress again that the viability of the implemented strategy of economic growth was based on re-establishing of some practices typical of the Soviet command-administrative system that inhibited the operation of economy at its full potential. Despite on the significant limitation some elements of a market economy still continued existing along with the dominating practices of a planned economy. However, the Belarusian authorities have not acknowledged this. They prefer to portray the Belarusian model of economic development as a social-oriented market economy with a high degree of state regulation. Literally, the role of the state in economic regulation in Belarus has created a type of state capitalism that makes any transformation towards market economy harder due to restraining the economic activity and significantly aggravates the economic situation in the country. We will see it in more details on the example of financial system.

\section{Financial repression as a 'life buoy' for the Belarusian economic model}

Acknowledging the positive relationship between financial deepening and economic growth, it urges us to place the analysis of the developments in the financial sector in the centre of the analysis of economic policy-making in Belarus. In the present section we overview the developments in the financial sector in Belarus over 90s in order to distinguish the key features of its evolution over the years of transition and to unveil to which extent the introduction of financial repression contributed to the economic recovery in Belarus in reality and what impact it had in the end on the further 
prospects of the Belarusian economic development. In turn we assume that the financial repression had a positive impact on the economic growth only in a short run, while in a long run it caused the decrease in real cash balances, finance shallowness that had an adverse impact on the economic growth.

This section will proceed as follows. First, we will deal with the developments in the banking sector, also briefly drawing on the developments in capital markets. Having the picture of the structure of the financial system, we will move to the discussion of the monetary policy in Belarus.

\section{Banking sector}

A two-tier banking system was established at the end of 1990 with the enacting of both the Act of the National Bank of Belarus and the Act on Banks and Banking Activity in the Republic of Belarus. This at the beginning of 2001 was replaced with the Banking Code. The National Bank of Belarus (NBB) was established from the Belarussian branch of the former Soviet Gosbank. As far as a second tier is concerned it consisted of two types of banks: specialist banks (which took place of the former Soviet specialist banks on the territory of the republic), and newly founded commercial banks. The first type included Belagroprombank (supply of credits to agriculture), Belpromstoribank (industry), Sberbank of Belarus (specialization on household deposits, financing budgetary programs and extending housing loans), Belbusinessbank (light industry and trade) and Belvnesheconombank (foreign trade) (Oesterreichische Nationalbank, 2000, p.85).

The number of newly founded commercial banks mushroomed in 1992-1994. Their development as market institutions was limited at the beginning of transition by the existed number of problems inherited from the past, such as a problem of bad debts, sectoral segmentation of specialised banks, the absence of capital markets, macroeconomic instability that undermined the credibility in the banking system and so forth. Sectoral segmentation of banks immediately brought to the surface the problem of creditor dependence and limited portfolio diversification, which made these banks exposed to the failure of their clients, which in their majority were the largest state-owned enterprises. Another problem typical of the post-socialist region was the appearance of 'pocket banks' that were mainly established by enterprises to serve the purpose of financing their own activities.

What was positive is the established relative independence of the National bank that was subordinated to the parliament according to the Act of the National Bank of Belarus of 1990. Moreover, its monetary emission function was limited in terms of the existed 5 per cent of GDP ceiling on the NBB credit to government. However, the practice of monetary and credit emission under highly negative rates to support state-owned enterprises remained pervasive in this period. The restrains imposed on the banking sector partly had the prudential reasons behind in terms of high reserve requirements (20 per cent in 1992, then reduced to 8-15 per cent in 1993 differentiating by banks). It was common around the region. However, the practice of negative interest rates had a significant negative impact undermining the principal of banks' operation. The problem of liquidity was being solved by permanent credit injections from the National Bank of Belarus at the very low refinancing rate that was also negative. Moreover, interest rate controls were introduced that were mainly reduced to margin controlled (between 3-5 per cent varying over the years). The problem of bad debts seemed endless. While it was solved in terms of the stock of bad 
debts simply by inflation wiping them out, the problem of flow of bad debts remained unresolved.

The positive changes in the banking sector development can be observed in 1995-95, when Bogdankevich stressed the policy of positive interest rates, tightened monetary expansion, reduced reserve requirements. Moreover, a fixed exchange rate introduced at the end of 1994 appeared to be the anchor of a stabilization policy. These measures were very effective in terms of curbing inflation, which was brought down from 4-digit rate in 1994 to 2-digit rate in 1996. It partly restored the credibility in the Belarusian rouble and provided the increase in the share of deposits of individuals. Moreover, 80 per cent of the credits were reallocated through market actions.

However, this policy was reversed in 1996 for the reasons stated earlier. Recalling what was mentioned above, to re-establish the practice of soft-budget constraints Lukashenko needed to gain a control over the banking system that by that time was partly liberalised.

For that it was necessary 1) to have power on the NBB that could be done through legitimising the subordination of the NB; 2) to nationalize the banking system

Lukashenko's attack on banks has started from criticizing them for reaping profits to his estimates reaching 1.2 billion, "when the government has debts to teachers, doctors, workers, pensioners". Lukashenko further accused banks in diverting profits from real sector into 'speculative transactions' such as interbank loans giving 600 per cent of profitability according to Lukashenko's estimates and sale and purchase of foreign currencies. Finally he blamed the bank clerks for having very high salaries (Silitski, 2002, p. 46)

The nationalization of the banking sector started from merging the state-owned National Savings Bank with the commercial Belarusbank in August 1995. Belarusbank had a bad loan portfolio that could be cleared by merging with healthier bank. Thus this consolidation with the National Savings Bank appeared to be a bailout for Belarusbank at the first glance. However, at the same time it turned Belarusbank into the state agent in channelling 'planned funds' to the real sector.

The further nationalisation proceeded with Presidential decree No 209 of May, 24 "On measures on Regulation of Banking Sector of the Republic of Belarus". It provided for approval of the list of banks servicing the state programmes. Moreover, it envisaged the measures to be undertaken by the government to increase its share and the share of state-owned enterprises in the statutory funds of the banks. Finally, it required the wages of bank clerks to be paid according to the tariff system for public sector.

This brought to an end the reforms in the banking sector. Since then direct government interference in the commercial activity of banks has been widely pervasive. In 1998 a presidential edict was issued to formalize and enhance the powers of the head of state over the National Bank of Belarus. Accordingly, the President of the Republic, Alexander Lukashenko, effectively has the authority to remove the chairperson of the NBB and to suspend and revoke any decisions of the NBB (Oesterreichische Nationalbank, 2000, p.85). With the enactment of the Banking Code in 2001 it seemed that everything had changed because it was stated that the only NBB reported to the President of Belarus. However, this was just a declaration and de jure the monetary authorities were left with little room for manoeuvre in formulating and implementing their policies. For example, while declaring that priority of macroeconomic stabilization should be given to tightening of creditmonetary policy, the National Bank was forced in 2001 by the authorities to finance 
the budget deficit created as a result of Lukashenko's pre-election policy to increase the average salary to USD 100. Moreover, this is not reflected as emission itself. Following the state's suggestion, the NBB has to buy government bonds afterwards to impose them upon the system-forming banks. ${ }^{3}$ The state-controlled commercial banking sector thus has executed quasi-fiscal duties while government budget deficits have been kept at relatively low levels.

At present, the banking sector in Belarus remains dominated by state-owned banks, in which both the state and large state-owned enterprises have preserved majority shares. Foreign ownership in banking sector reaches just 12 per cent.

The ownership of large state-owned enterprises in banks creates a problem of intertwining owner-creditor roles, which hampers financial prudence. There are currently around 28 commercial banks, from which the six largest are so-called system forming, which have serviced the clientele inherited from the previous system and have continued to serve government programmes assisting certain economic sectors. While being the state agents in servicing the government social-oriented projects and financing budget deficit the system-forming banks have been eligible for correspondent support of authorities in kind of setting of relatively soft individual indicators of banking performance for them, much less loan-loss provisioning than that required by regulation, financing of liquidity gaps at the account of centralized credits etc. These banks control above 90 per cent of total assets, 90 per cent of enterprise lending, almost 100 per cent of lending to households and their capital accounts for 77 per cent of total banking capital. Thus the banking sector in Belarus is considered highly monopolized and concentrated. It constrains the development of commercial banks in Belarus and provides little competition in the system. The stages in monopolization of the banking sector in Belarus must be stressed. In the mid 1990s small and medium banks were deprived the possibility of serving resource-capacious clients because the accounts of the latter were transferred to the Joint-Stock Savings Bank 'Belarusbank', the monopolist in servicing households. Afterwards nonmonopolistic banks were deprived of licenses for cash collection, which caused monopolization of cash flows. The latter could be also explained by the intention of the government to get rid of the 'black market'. The last requirement of the National Bank of the Republic of Belarus was to increase net worth up to 10 million euro by 1 January 2002 in order to keep license on servicing individuals in attracting savings. Not all the Belarusian banks managed to cope with this decree. However, it is fair to note that not all the banks tried to do this. In terms of high monopolization of the banking sector, directive attachment of large state-owned enterprises to certain banks, small per cent of private ownership, sectoral segmentation and what is directly related to the above case, domination of Belarusbank in servicing households and the fact that presently it is the only bank which is equipped with a public deposit guarantee, small and medium-sized commercial banks (SMCBs) have had to look for their own niches to work. Taking into account the problem of Rouble liquidity that most of the systemforming banks frequently experience, lending credits on inter-bank market can be named as one of such SMCBs' niches. Such commercial banks as 'Tekhnobank' and 'Zolotoj Taler' also work with purchase and sale of foreign currency.

On the other hand, the last measure used by the authorities to increase the net worth by up to 10 million euro aimed at increasing capitalization of the banking sector. The present level of capitalization is too low and accounts only for 4.7 per cent of GDP, which (if to speculate ahead and to consider this problem in light of the forthcoming Belarus-Russia integration) is incompatible with the same indicator in Russia. The depth of financial intermediation is also insufficient. The ratio of total 
banks' assets to GDP accounts only for 38 per cent versus for example 70 per cent in Hungary, where it is regarded as relatively low. The ratio of credit to economy in relative terms also remains low (in average 15.6 per cent in 1995-1999), despite this amount seems to be high in absolute terms, given the pattern of soft budget constraints exercised in Belarus.

While the successful consolidation and re-capitalization of banks within the reforming regulatory framework facilitated the elimination of bad debts in the most of the CEE countries' banking sector, the sustained policy of soft budget constraints and directed credits has aggravated the problem of bad debts and undermined solvency of the Belarusian banking sector. Overall, bad debts account for 13 and 17 per cent of total banks' credits whereas according to the international standards their amount should not exceed 5 per cent. Since the Belarusian banks frequently exercise such practices as rescheduling debts and prolonging the real amount of bad debts this is even higher than reported.

Little progress has also been made towards reforming the regulatory framework. Notorious lack of 'independence' of NBB is one of the convincing facts in this respect. Amongst others the weaknesses the present bankruptcy law can be noted, which was and is, rarely implemented in practice, and reveals shortcomings in banks accounting practices.

Here there is also need to briefly draw on developments in capital markets. Despite, some steps done at the beginning of transition to build up the system of capital circulation in Belarus, virtually capital markets do not exist due to the number of reasons. First, the policy of negative or low positive interest rates has made any financial instruments completely unattractive for potential investors. Second, privatisation as such did not happen that potentially excluded any possibilities of existence of private securities market. It gives more room for manoeuvring to the government for increasing its gains from seingniorage. The securities market is mostly represented by the government securities such as short-term liabilities (GKOs), which along with credit emission remain one of main sources of financing the government deficit. Thus, one can conclude that the capital market in Belarus is very shallow and barely can be considered as playing any role at all in enterprises' financing.

So, one can conclude that Belarus in comparison with most of the other transition economies has achieved little progress in reforming its banking sector and developing capital markets. Its pattern of financial development is solely bank-based, while in other transition economies the role of capital markets in financing enterprise activities has been increasing over years of transition. Moreover, banking activity itself is ineffective and highly restrained by the government, which has turned the banking sector into a 'tool' for maintaining the Belarusian economic model.

\section{Monetary policy}

The key issue for the Belarusian authorities at the beginning of transition was to preserve the rouble zone that replaced the Soviet system and was supposed to help in creating a common economic space throughout the CIS. The Central Bank of Russia had a monopoly on currency emission within the rouble zone but the central banks of other CIS countries were allowed to issue credits to enterprises, or to cover budget deficits. This created massive opportunities for free-riding on Russia's efforts at economic reform, and was a system of transfers from Russia to other states. The governments and national banks of smaller Soviet republics could afford an 
uncontrolled emission of money as inflation effects were spread widely throughout the post-Soviet space. Its free rider status allowed the Belarusian government to print enough money to pay wages and credit state companies and collective farms (kolkhozy) while suffering only a small inflationary impact. At the same time, as Russia attempted to restrict the supply of money, the deficit between cash and noncash money in Belarus began to increase. The shortage of cash money triggered the introduction of Belarus' own currency, the Belarusian rouble (known as 'zaichik', or hare). Non-cash zaichik was converted at a rate 1:5 against non-cash Russian Roubles, whereas the banknotes were exchanged at a rate 1:10. These variations in rates created favourable conditions for highly profitable speculative activity. The effect of these policies was a large transfer of wealth from Russia to Belarus, equivalent to 13 per cent of its GDP in 1992 and 8 per cent of its GDP in seven months of 1993 prior to the final break up of the rouble zone.

The economic impact of the rouble zone on Russia meant that it could not be maintained forever. Russian monetary reform in July 1993 and inflationary pressures on the exchange rate parity between zaichik and the Russian rouble put the end to the rouble zone and forced Belarus to announce the Belarusian rouble as the only legitimate means of payments in $1994 .{ }^{4}$ As a consequence of the policy of money emission levels of hyperinflation rocketed from 1,560 per cent in 1992 to 2,221 per cent in 1994.

Some efforts were made from 1995 to control inflation and stiffen monetary policy that was already discussed earlier. However, these measures did not last. The deterioration of the real sector of the economy led the Belarusian authorities to loosen monetary policy once more. The inability of the government to maintain its exchange rate commitments, because of insufficient foreign exchange reserves, led to devaluation. From 1996 the country has turned back to implementing measures typical of a planned economy named above.

Alongside negative interest rates, margins controls, directed credits and high reserve requirements policies of multiple exchange rate and multiple interest rates were introduced. As far the latter is concerned the official rate was the announced refinancing rate, at which a small amount of the credit market has been served. The factual refinancing interest rate was in fact the rate at which the National bank granted credits. As noted by Rusakevich (2000, pp. 19-20) this rate was composed of the following main interest rates:

1. Highly privileged rate on directed credits granted for housing construction programme. It was usually one tenth of the announced refinancing interest rate. With inflation between 63.9 per cent and 293.7 per cent pa in 1997-1999, this rate was only 5 per cent pa and credit was granted under the condition that it was to be repaid within 40 years. These credits issued at the expense of directed credits amounted to between 6 per cent and 15 per cent of the total bank credits to the economy in 1996-1999.

2. Privileged rate on majority directed credits to agriculture. In 1997-1999 this was half of the announced rate.

3. The official refinancing rate was mainly used as a rate of return on GKO (short-term government liabilities) of the first circulation.

4. Rates on market instruments of short-term financing (Lombard and overnight credits) that are one and a half times higher than the announced refinancing rate, and compensated privileged interest rates.

The fact that the real factual refinancing rate was more favourable for banks than the real deposit rate encouraged banks to appeal to cheap NBB credit resources rather 
than to attract means of individuals and enterprises into deposits. Actually, the real deposit interest rates were not so high during 1995-96, and even negative afterwards, to activate the latter anyway.

To conclude this section regarding the mechanisms of refinancing used in Belarus over the years of transition, once again there is need to emphasize such the peculiar nature of the Belarusian monetary policy-making as directed credits at rates much lower the NBB announced refinancing rate. Thus, as Rusakevich (2000, p.20) postulates, market allocation of credit resources of the lender of the last resort were replaced by the administrative reallocation of credit resources in favour of the branches of economy, which were regarded by the Belarusian authorities as priority. These are housing construction and agriculture. The traditional ways of channelling these credits were, and still remain to a lesser extent, as follows:

1. The National Bank has channelled these cheap credits through the banks, which are government agents in servicing social-cum-economic oriented programmes. They are Belarusbank, mainly used in financing housing construction, and Agroprombank, which services the agricultural sector.

2. The National Bank has granted directed credits to the Ministry of Finance, which in turn has reallocated them between the aforementioned banks.

Basically, these credits are potentially bad debts. In this case, the National bank or the Ministry of Finance apply debts-for-equity swaps schemes to these banks, by this increasing state ownership in them. This action has another implication: it makes these banks' performance looking better statistically (because the percent of bad debts is decreasing whilst capital increases), but in reality it is an artificial growth of capital.

The above directed or emission credits as a way of the state reallocating financial flows, particularly via channelling credits directly from the NBB to commercial banks, can be regarded as quasi-budget expenses. This is why Belarus was among the limited number of post-communist countries that managed to keep budget deficit at level less than 3 per cent of GDP.

With increasing inflation and the Belarusian Rouble losing its credibility, dollarization of the economy became obvious. ${ }^{5}$ One should note that with the ratio of Foreign Currency Deposits to broad money exceeding 30 per cent, Belarus can be classified as a highly dollarized economy.

While acknowledging that emission policy has remained the dominant monetary instrument in Belarus over the years of transition, the majority of other transition economies, realising the inflationary nature of money creation, have switched to using more market instruments to carry out monetary policy. Consequently, by reducing money emission, these countries have cut themselves off from gains coming in the form of seigniorage and inflation tax, while Belarus tried to benefit from the latter.

Table 4.1 shows annually dynamics of the level of seiniorage and inflation tax as a percentage of GDP in Belarus. ${ }^{6}$ In Belarus the level of inflation tax was really high amounting to 33.24 per cent in 1995 . However, the monetary policy tightening in 1995 had a positive effect on the reduction in the levels of both inflation tax and seigniorage in 1996 to 3.48 per cent and 2.78 per cent (from 4.17 per cent in 1995) respectively. In 1998-1999 primarily due to the aftermath of the Russian crisis both levels of seigniorage and inflation tax increased significantly and relatively fell down in 2000.

Table 4.1 Seigniorage and inflation tax in Belarus in 1995-2000 (as a percentage of GDP) 
1995

1996

1997

1998

1999

2000
Seigniorage

4.17

2.78

3.56

5.85

3.91

2.52
Inflation tax

36.5

3.42

4.95

7.27

19.35

8.4

Source: author's calculations

To recall that housing construction and agriculture are the main sectors of the economy absorbing emission credits, it is fair to note that in reality the primary source of financing of these branches appeared to be inflation tax, which fell on individuals and enterprises.

Rusakevich (2000, p.22) gives the following example. During 1997-99 Belarusian citizens were granted privileged credits by at the amount of BRB 72 billions NBB for housing construction purposes. During this time, the Belarusian rouble was devalued by BRB 75 billion. In other words, at the expense of inflation tax on the Belarusian citizens the state built around ten thousand apartments. He also estimates that the total emission financing of BRB 120 billions in 1997-99 led to depreciation of money of individuals and enterprises by BRB 245 billions.

Here there is need to look at the issue of interrelation of seigniorage and inflation in more details. The inflationary nature of money creation is well recognised. Since seigniorage is a tax, graphically it can be performed as a Laffer curve with respect to the rate of money growth. Imagining the bell-shaped form of the inflation-tax Laffer curve, there is a maximum point at which seigniorage is optimised under a certain rate of money growth that can be called the revenue-maximizing rate of money growth. Under the moderate rate of money growth less than the revenue-maximizing one, seigniorage exhibits upward trend. When a money growth rate exceeds the revenuemaximizing one, inflation rate increases in greater proportion than the money growth rate. This finally leads to the decline in real cash balances or in other words to the proportionally greater reduction in the tax base for seigniorage compared with the increase in the tax rate itself. As a result the revenue declines which graphically puts seigniorage on the downward sloping side of the Laffer curve. Thus, basically there is a kind of trade-off between a higher rate of money growth increasing seigniorage and the associated inflation decreasing it by lowering demand for money. When seigniorage is first imposed that is at the beginning of inflation, there is no revenuemaximizing growth rate as such. The higher the growth is, the higher the revenue due to the lag in expectations. However, after households start correctly estimating expected inflation and adjustment in real cash balances tend to be instantaneous, the higher money growth leads to the higher inflation and correspondingly to decrease in demand for real money and fall in the revenue from seigniorage. It made productivity of this tax ineffective. ${ }^{7}$ Moreover, it has another more important implication. Despite nominal money supply continues to rise, real cash balances exhibit declining resulting in finance shallowness. The latter negatively influences the economic growth.

That is exactly what happened in Belarus in the late 90s when the government introduced financial repression. When the government reintroduced the practice of inflationary financing in the late 1996 together with the policy of negative interest rates, it boosted the aggregate demand resulting in economic growth in 1997. However, it started to decline since then, unveiling the ineffectiveness of monetary 
policy-making. The coefficient of monetization that is the measure of financial deepening ${ }^{8}$ decreased from 69 per cent of GDP in 1990 to 6.4 per cent in 1994. In 1995-96 it slightly increased from 6.9 to 8.8 per cent due the monetary tightening policy and exhibited the further fall from 1997, reaching its minimum value of 5 per cent in 2000. ${ }^{9}$ However, while acknowledging the problem of finance shallowness the authorities find its solution in increasing demand for money elaborating a package of measures ${ }^{10}$ that are believed to increase the coefficient of monetization. What is interesting is that the figures of monetary growth and inflation are stated as the directions in the government programme of money demand increase, without supplying any calculations of these rates or at least explaining their rational origin. Moreover, these guidelines literally say, “...in 2002 inflation should be restricted up to 20-27 per cent". Will it be done at the expense of freezing prices or through controlling maximum profitability rates, or due to the monetary tightening? It does not become clearer from the next guideline either: "...money supply growth is envisaged to be within 39-117 per cent bounds provided by the necessity of National Bank participation in financing budget deficit at the amount of BRB152 bln (including BRB 132 bln for housing construction), refinancing of the banks at the amount of BRB 55 bln....”.

To conclude, first of all one can see that the Belarusian pattern of financial development was significantly differed from the CEECs and the majority of the FSU countries. Second, in 1996 financial repression was introduced to provide sustainability of the Belarusian model of economic development. Third, the above analysis reveals that financial repression had rather short-term positive effects on economic development, but in a long run it appeared to be disrupting the economy.

\section{Belarus and Russia: the prospects of 'integration model'}

Since Belarus embarked upon 'transformation' it has become more open, and integrated into the global economy. Thus, there is need to examine how the process of globalisation is shaping the present and future perspective of its economic development.

Most of the CEE transition economies from the early beginning of transition have pursued the strategy of joining the EU that required the progress in transformation towards market to be achieved, building democracy and complying with EU accession requirements. The case of Belarus was different although initially nothing put obstacles on the way to follow the CEECs in their strategic choice. Historical and cultural background, initial conditions, political stance, reluctance of reforming the economy, looking for the easiest way to preserve the 'status quo' and provide the viability of those in power altogether determined the Belarusian strategy in favour of Russia-Belarus integration as a way of integrating into the global economy. What is interesting about this integration issue is that it is always based on populist grounds, and leaves a lot of doubt about its future perspectives.

In the consideration of Russia-Belarus relations I shall omit the sequence of signing all the agreements between both countries as they can be regarded as 'declarations on paper' and are not worth much attention to pay here. In this context, it is more important to consider economic advantages that Belarus gained as a result of developing the integration issue. It cannot be denied that economic integration with Russia contributed to revitalization of the Belarusian economy in terms of its further deterioration and provided it with a valuable alternative in the aftermath of international isolation in which the country fell after the November 1996 referendum. 
Commencing from a write-off of the Belarus US\$ 1 billion debt to Russia in March 1996, than Belarus received an unlimited access to the Russian market and the opportunity to purchase oil and gas at the relatively low price that is 50 per cent of the world price level for oil and 16 per cent for gas. The Custom union between the two states established in 1995 put Belarus into control of almost all Russian exports and imports to the West, as they cross Belarusian border. The significant losses of nonreceived custom payments by the budget of the Russian side finally led to the collapse of the Custom union that witnessed in favour of the fact that this issue was not worked out properly and both countries were not ready for this kind of unification. More important was the fact that Russia agreed to establish trade relations with Belarus, which mainly occurred in barter, and only 8 per cent of trade was carried out on cash basis. The trade practices between them were such that the appreciation of the real exchange rate did not immediately harm the Russian-directed industrial exports. The barter transactions usually took shape of exchange of the goods in which sides obliged to supply each other with amounts of products at a price fixed in the USD dollars according to the official exchange rates. Basically, Belarus exchanged its overpriced industrial products for under-priced oil and gas from Russia, whereas money played little role in the mutual trade. The years that followed the formation of the community and the Union witnessed a rapid growth of the Russia-Belarus trade. The latter was achieved mostly due to the proliferation of the barter schemes, actively lobbied by Lukashenko in the course of his visit to Russian regions. Altogether, the annual amount of hidden Russian subsidy of the Belarusian economy was estimated to reach USD 1.5-2 billion in 1997-98 or 10 per cent of the consolidated Russia's budget (USD 25 billion). ${ }^{11}$ In 2002 only due to the reached between Russia and Belarus 5 per cent decrease in price for gas these 'subsidies' increased by USD 63.5 million a year.

From the above one can conclude that mainly due to these subsides, namely low energy price and favourable barter deals with Russia, Lukashenko would not have been able to sustain his 'transformation' model under the constant deterioration of economic situation, whereas the amount of loss-making enterprises in industry reached 44 per cent and in agriculture 61.9 per cent as at June 2002 (Zaiko, L., 2002); depreciation of equipment in industry increased from 50 to 76 per cent during 19921997 and reached 80 per cent by the end of the decade (Godin, 2001, p.156; Bogdankevich, 2002, p.4); growing enterprise arrears, and chronic delays in salary payments.

What is remarkable in this situation is the fact that Belarus became closely integrated with Russia despite a low convergence of both economies and institutional homogeneity, in other words, avoiding transformation as such.

However there is still a need to distinguish two periods in Russia-Belarus relations drawing on the change of leadership in Russia. With Putin's coming to power, all attempts of Lukashenko to carry out a policy of isolation with the West become increasingly futile. Putin has stressed upon the policy of making Russian development Europe-based. Moreover, it has been strengthened by the change in geopolitical course. With Social Democrats at the lead headed by Schröder, the German geopolitical strategy was altered to support the strategic co-operation with Russia.

With Putin's leadership there began a revitalization of Russia's economy and renewal of its strength as a world power. Russia was neither prepared nor willing to pay for its integration with Belarus any longer.

Whether this integration happens nobody can answer this question with full assurance. However, at least some positive assumptions can be made about coming 
restructuring of the Belarusian economy and further liberalisation of the financial sector $^{12}$. They will inevitably take place either under the pressure from Russia or due to the necessity of radical changes in a view of the worsening of macroeconomic situation.

\section{Conclusion}

On reviewing policy-making in Belarus over the years of transition, from a financial sector dimension, and looking at the domestic response of the Belarusian authorities to the transition challenges, the following conclusions can be made.

First, while CEE countries, and the Baltics countries, and by that time the majority of the CIS countries embarked upon the transformation of their economies, including the financial sector, Belarus can hardly be regarded as having undertaken any transformation at all. In other words, the Belarusian reforms were all fragmentary and controversial. Belarus in its present economic development made a step backward, in an attempt to break away from transitional challenges and to switch to the elements of a planned economy.

Second, while the Belarusian-style 'transformation' model has been widely regarded by the Belarusian authorities as driving towards a social-oriented market economy with a high degree of the state participation in the national economy regulation, in reality the economic course was highly politicized servicing the interests of the ruling nomenklatura. With time this important role of the state in the national socio-economic development has taken a shape of state capitalism that hindered any transformation towards market economy and significantly aggravated the economic situation in Belarus.

Third, despite undertaking no transformation per se, and achieving no macroeconomic stability, Belarus has nevertheless demonstrated recovery from 1997 achieved on the grounds of inflationary creation and state stimulation of demand through policies of an unprecedented credit expansion, negative interest rates, and administrative price control attributed to financial repression.

Forth, financial repression had rather short-term positive effects on economic development, but in a long run it appeared to be disrupting the economy.

Fifth, the chosen way of integration into the global economy through the monetary unification with Russia, can be explained by the passiveness and unwillingness of the Belarussian authorities to reform the national economy, whereas an easier way could exist to sustain it, that is to say through relations with Russia, and at the same time preserving political viability of the Belarusian leadership.

Six, it is very difficult to speculate about the prospective of Belarus in regard to its economic development and particularly in the financial sector, because the economic life of Belarus, as it was mentioned above is highly dependent on the political climate. However, it is likely that its further development is determined by the prospects of Russia-Belarus Monetary Unification.

\section{Notes}

\footnotetext{
${ }^{1}$ Some transition economies, particularly Poland, Czech Republic, Estonia, adopted stabilization programme based on exchange rate regimes. So basically there have been two main forms of stabilization programmes: one money-based, the other exchange rate based.
} 


\footnotetext{
${ }^{2}$ For example, in September 1992 there was signed an agreement on military co-operation of Belarus with Russia, which extended stay of Russian troops in Belarus until 2000.

3 The term 'system-forming banks' primarily means the high importance of these banks for the economy of Belarus. They serve the major Belarusian economic sectors. These banks are to be the state agents in servicing prior state socio-economic projects. They hold dominative position in market of banking services. Given their parlous financial position (to be expanded further in text) if one of them goes down, it has negative spillover effects over the whole economy as per domino effect.

${ }^{4}$ For more details on the rouble zone and arrangements of Belarus and Russia within it see Silitski, 2002 and Conway 1995.

5 The term 'dollarization' serves as shorthand for the use of any foreign currency.

${ }^{6}$ Seigniorage is calculated as the annual increase in the monetary base, divided by nominal GDP. Inflation tax is calculated as the inflation rate times the real stock of money base. Inflation rate, used to measure Inflation tax is measured on GDP deflator, because it is the government who benefits from inflation tax. It buys a much wider range of goods that the CPI covers. Another reason for using GDP deflator in these calculations, is that inflation tax is expressed as a percent of GDP.

${ }^{7}$ For more details see Cagan (1956), Romer (1996), Boichanka (2001).

${ }^{8}$ It is calculated as a ratio of rouble broad money (M3) to nominal GDP.

${ }^{9}$ The source of the data is the Draft of the Concept of Development of Banking System of the Republic of Belarus in 2001-2010.

${ }^{10}$ Resolution of the Council of Ministers of Belarus and the National Bank of Belarus of December, 28, 2001 "About the programme of the measures to increase demand for money in 2002"

${ }^{11}$ Silitski, 2002; interview with S. Stankevich, a specialist of the Division of Foreign Currency Transactions, JSSB 'Belarusbank', Minsk, March 2002.

${ }^{12}$ Some steps towards its liberalisation have been made starting from 2000 . They were removing the mechanism of multiple exchange rate through the unification of the exchange rate occurred, removing restrictions in exchange market and achieving convertibility of current account, introducing the policy of positive interest rates, relative monetary tightening and so forth.
} 